Jurnal E-Bis (Ekonomi-Bisnis)

Vol. 5 No.2 (2021) pp. 395-408

https://jurnal.politeknik-kebumen.ac.id/index.php/E-Bis

p-ISSN : 2580-2062 e-ISSN : 2622-3368

\title{
Pengaruh Total Asset Terhadap Return On Assets Dan Return On Equity Menjelang Pandemi Covid-19 Pada PT. Astra International Tbk Periode 2016-2020
}

\author{
Ibnu Sabil Al ansori ${ }^{1 *}$, Ratnoto ${ }^{2}$, Muthmainnah ${ }^{3}$ \\ ${ }^{123}$ Manajemen Bisnis, Politeknik Piksi Ganesha, Indonesia
}

*Email : ibnusabilalansori@gmail.com

Doi : https://doi.org/10.37339/e-bis.v5i2.675

Diterbitkan oleh Politeknik Dharma Patria Kebumen

Info Artikel

Diterima :

2021-8-27

Diperbaiki :

2021-8-27

Disetujui :

2021-10-6

\begin{abstract}
ABSTRAK
Pandemi Covid-19 jadi pemicu menyusutnya energi beli warga selama satu tahun terkahir ini di hampir seluruh dunia, sehingga mengakibatkan menurunnya tingkat penjualan perusahaan termasuk PT. Astra International Tbk, riset ini bertujuan buat mengukur pengaruh Total Asset terhadap bagian dari rasio profitabilitas Return On Assets dan Return On Equity menjelang Pandemi Covid-19 dengan menggunakan metode regresi linear menggunakan SPSS 26 dengan hasil menunjukan nilai $F$ hitung $<$ dari $F$ tabel untuk $X$ terhadap $\mathrm{Y}_{1}(0,000<7,71$ dan $\mathrm{X})$ dan $\mathrm{X}$ terhadap $\mathrm{Y}_{2}(0,001>7,71)$ dan dari output koefisien determinasi $\left(\mathrm{r}^{2}\right)$ didapatkan nilai $\mathrm{X}$ terhadap $\mathrm{Y}_{1}$ dan $\mathrm{X}$ terhadap $\mathrm{Y}_{2}$ di angka yang sama yakni 0,000 , dan mengindikasikan bahwa dari hasil uji periode 2016-2020 di PT. Astra International Tbk melaporkan tidak terdapatnya pengaruh antara Total Asset terhadap Return On Assets dan Return On Equity.
\end{abstract}

Kata Kunci: Total Asset, Return On Assets, Return On Equity, Covid-19

\begin{abstract}
The Covid-19 pandemic has triggered a decline in the purchasing energy of citizens for the past year in almost all parts of the world, resulting in a decline in the level of sales of companies including PT. Astra International Tbk, this study aims to measure the effect of Total Assets on the part of the profitability ratios of Return On Assets and Return On Equity ahead of the Covid-19 Pandemic by using the linear regression method using SPSS 26 with the results showing the calculated $F$ value < from $F$ table for $X$ to $Y 1$ $(0.000<7.71$ and $X)$ and $X$ to $Y 2(0.001>7.71)$ and from the output of the coefficient of determination $(r 2)$ it is found that the value of $X$ against $Y 1$ and $X$ against $Y 2$ is the same number, namely 0.000 , and indicates that the test results period 2016-2020 at PT. Astra International Tbk reported that there is no influence between Total Assets on Return On Assets and Return On Equity.
\end{abstract}

Keywords: Total Asset, Return On Assets, Return On Equity, Covid-19 


\section{PENDAHULUAN}

Munculnya Pandemi Covid-19 membawa beragam dampak bagi pelaku usaha dan industri di Indonesia. Hal ini dikarenakan banyaknya industri mengalami penurunan tingkat penjualan dan aktivitas produksi akibat kebijakan yang dikeluarkan pemerintah guna menghambat penyebaran Pandemi Covid-19. Perubahan tingkat penjualan ini membuat nilai rasio profitabilitas perusahaan berubah diantaranya adalah menurunnya Return On Assets ataupun Return On Equity yang mana keduanya ialah suatu yang fital yang menggambarkan bagaimana kinerja suatu perseroan atau perusahaan dalam menilai tingkat pengembalian aset dan modal perusahaan dan menjadi salah satu penentu masa depan perusahaan.

Salah satu kekuatan terbesar perusahaan dalam menyokong pertumbuhan dan pengembangannya ialah faktor modal, dimana dalam memperoleh modal tersebut tentunya terdapat beberapa faktor penilaian yang dipakai para penanam modal atau biasa disebut investor ataupun kreditur, menurut Andini, Rifka Kharisma mereka sangat pilih-pilih tentang perusahaan untuk berinvestasi, alasannya karena nilai perusahaan biasanya digunakan sebagai bahan pertimbangan oleh para investor dalam menanamkan modalnya (Andini \& Kharisma, 2021), mereka biasanya menggunakan analisis fundamental sebagai pertimbangan layak atau tidaknya modal tersebut diberikan atau apakah perusahaan tersebut dapat memberikan income yang layak bagi mereka sebagai imbalan atas modal yang diberikan, salah satu rasio yang biasa atau sering dipakai dalam menganalisa kondisi performa industry/perusahaan dalam hal keuangan yaitu Return On Asset dan Return On Equity dimana rasio tersebut dapat memberikan gambaran secara ringkas bagaimana perusahaan tersebut dapat memberikan profit terhadap aset dan modalnya, seperti Return On Assets, dimana terus menjadi kecil( rendah) rasio ini, terus menjadi kurang baik begitu pula kebalikannya.

Dalam pandangan sebagian investor makin besar harta yang perusahaan miliki membuat tingkatan pengembaliannya bertambah besar pula dan cenderung kebanyakan Investor akan tertarik pada perusahaan yang berkembang pesat ketika hendak berinvestasi dan berpandangan bahwa tingkat Return On Assets atau Return On Equity dengan angka meningkat seiring dengan jumlah asetnya tentunya menjadikan perusahaan layak dipertimbangkan sebagai sarana untuk berinvestasi kedepannya, lalu apakah hal tersebut selalu benar adanya, banyak kondisi yang perlu dipertimbangkan sebagai analilis untuk menentukan layak tidaknya suatu investasi dalam waktu jangka panjang pada suatu perusahaan, dalam analisis kinerja perusahaan setidaknya diperlukan data dari laporan keuangan yang dipunyai perusahaan tersebut untuk menilai kinerjanya, dan supaya penilaian yang dilakukan dapat lebih akurat. Sebagaimana telah diketahui Pandemi Covid-19 sudah masuk ke Indonesia kurang lebih 2 maret 2020 dan mulai sejak saat itu kebijakan-kebijakan mulai diterapkan sehingga hampir seluruh sektor baik pendidikan termasuk perusahaan-perusahaan di Indonesia mulai terkena dampaknya yang membuat sebagiannya vakum, untuk menemukan bagaimana pengaruh Total Asset terhadap Return On Assets dan Return On Equity dalam menilai kinerja suatu perusahan dan seberapa berpengaruhnya Pandemi Covid-19 pada level penyusutan Return On Assets ataupun Return On Equity maka diperlukan perbandingan data nilai Total Asset, Return On Assets juga Return On Equity menjelang Pandemi Covid-19 sebagai tolak 
ukur kinerja perusahaan dan tingkat penyusutan nilai Return On Assets ataupun Return On Equity setidaknya sepanjang periode lima tahun terkahir.

PT. Astra International Tbk, sebelumnya bernama Astra International Inc, adalah sebuah perusahaan yang bergerak pada perdagangan umum yang didirikan pada tahun 1957 dan sejak tahun 1990 berubah namanya menjadi PT. Astra International Tbk dengan model bisnis berbasis sinergi dan mempunyai berbagai segmen bisnis seperti otomotif, jasa keuangan properti, teknologi informasi dan lainnya, berikut ini adalah tabel nilai Total Asset, Return On Assets, Return On Equity hasil pengutipan laporan data keuangan yang telah di publish PT Astra Internatioanl Tbk di situs resminya pada lima tahun terakhir yaitu periode tahun 20162020, sebagai berikut :

Tabel nilai Total Asset, Return On Assets dan Return On Equity PT. Astra International Tbk Tahun 2016-202

\begin{tabular}{|c|c|c|c|}
\hline Tahun & Total Asset & Return On Assets & Return On Equity \\
\hline 2016 & 261,855 & $7 \%$ & $13 \%$ \\
\hline 2017 & 295,830 & $8 \%$ & $15 \%$ \\
\hline 2018 & 344,711 & $8 \%$ & $16 \%$ \\
\hline 2019 & 351,958 & $8 \%$ & $14 \%$ \\
\hline 2020 & 338,203 & $5 \%$ & $10 \%$ \\
\hline
\end{tabular}

Sumber : www.idx.co.id

Seperti yang terlihat tabel di atas memeperlihatkan nilai Total Asset pada dari tahun 2016 hingga 2020 terjadi kenaikan tahun demi tahun terkecuali pada tahun terakhir 2020 terjadi penurunan sekitar 3,9 \% nilai aset dari tahun sebelumnya dikarenakan adanya penyusutan nilai aktiva tetap sementara untuk persentase nilai Return On Asset dari tahun 2016 sampai tahun 2020 memiliki nilai cukup stabil hingga 2019 terkecuali pada tahun 2020 nilai nya menyusut secara spontan sama halnya dengan nilai Return On Equity hal tersebut dipengaruhi oleh oleh beberapa hal yang salah satunya akibat Pandemi Covid-19 yang memicu beban penjualan bertambah dan menurunnya kuantitas penjualan, Return On Assets juga Return On Equity merupakan rasio yang menjadi sebagian tolak ukur baik buruknya kinerja perusahaan secara efektif dan mengukur secara langsung tingkat pengembalian terhadap Total Asset dan ekuitas pemegang saham dimana dengan rasio tersebut investor, manajemen perusahaan ataupun pihak lainnya dapat menilai berapa persen tingkat keberhasilan penggunaan aktiva dalam menghasilkan profit dan dapat mengukur secara langsung besarnya keuntungan yang diterima dari jumlah dana atau ekuitas yang diberikan.

Berdasarkan penjelasan yang sudah dipaparkan sebelumnya, menjadi alasan penulis membuat pembahasan penelitian dengan tema "Pengaruh Total Assets Terhadap Return On Asset dan Return On Equity Menjelang Pandemi Covid-19 Pada PT. Astra International Tbk Periode 2016-2020".

Dari penilitan ini peneliti berharap dapat memberikan pegetahuan tambahan kepada masyarakat terkhusus bagi para calon investor dalam mempertimbangkan langkah investasi yang akan diambil dengan lebih obyektif dan menilai suatu kinerja dan prospek suatu perusahaan dengan lebih fleksibel juga semoga PT. Astra International Tbk dapat 
mengembangkan strategi marketing dan penggunaan aset lebih baik agar dapat menstabilkan dan meningkatkan nilai Return On Assets juga Return On Equity dari aset maupun modal yang dimiliki terlebih pada masa krisis karena nilai rasio profitabilitas tersebut biasa digunakan sebagai analisis fundamental oleh pasar modal sebagai dasar pertimbangan dalam berinvestasi.

\section{KAJIAN PUSTAKA}

\subsection{Modal (Capital)}

Secara umum modal atau Capital adalah sumber daya yang dimiliki perusahaan untuk mengolah usahanya dalam rangka menghasilkan produk yang memiliki nilai jual di masyarakat untuk memperoleh keuntungan dari sumber daya yang digunakan. Modal terfokus pada sumber daya moneter yang bisa dipakai bisnis sebagai anggaran operasionalnya, uang tunai, mesin, peralatan, dan sumber daya lainnya adalah contohnya. Capital yang digunakan oleh perusahaan tergantung dari ukuran skala besar kecilnya suatu perusahaan, maka dari itu modal merupakan faktor utama dalam sebuah bisnis, tanpa adanya modal anda tidak dapat berbisnis.

\subsection{Aktiva (Asset)}

Aktiva/Assets ialah bagian elemen dalam neraca pada suatu industri. Pengertian aktiva atau umumnya disebut aset secara etimologi berasal dari kata bahasa Inggris yang diterjemahkan dalam kata Asset. Secara etimologi aset didefinisikan yakni barang (thing) atau sesuatu (anything) yang memiliki nilai (economic value), nilai komersial (comercial value), atau nilai tukar (excange value) yang dimiliki oleh instansi, organisasi, badan usaha, individu ataupun perorangan (Sofwan \& Sulastri, 2019). Aset merupakan sesuatu yang mendasari adanya produksi dalam perusahaan sehingga aset boleh dikatakan sebagai pondasi yang mendasari berjalannya suatu perusahaan dan perkembangannya, oleh karena itu nilai aset suatu perusahaan juga dapat menjadi suatu ukuran besarnya suatu perusahaan, aset ini juga dapat bisa difahami sebagai "stok" yang dapat ditarik ke atas, dibangun ke atas, atau dapat dikembangkan dan merupakan sumber daya yang dapat dibagikan atau ditransfer lintas generasi (Siska Devi Ratna Sari S.Kom.I., 2020), dengan demikian dapat di ketahui bahwa aset yang dimiliki perusahaan dapat dikembangkan menjadi sesuatu yang dapat bernilai lebih apabila dikelola dengan baik dan juga dapat dibagikan kepada pihak bersangkutan yang memiliki hak atas aset tersebut di masa mendatang.

Aset sendiri terbagi menjadi beberapa jenis , diantaranya:

\subsubsection{Aktiva Lancar}

Aktiva lancar merupakan aktiva dengan ekspektasi mampu memberikan daya guna bagi siklus operasi perusahaan untuk waktu yang lama (sekitar satu tahun). Kas, surat berharga, piutang dagang, persediaan, investasi jangka pendek, penghasilan yang masih harus diterima dan akunakun lainnya, dan biaya yang harus dibayar adalah jenis aset lancar yang paling umum kita tahu.

\subsubsection{Investasi}

Investasi adalah komitmen finansial yang dibuat oleh seseorang, kelompok, atau organisasi yang digunakan oleh perusahaan untuk mengembangkan perusahaan tersebut dengan adanya 
distribusi hasil yang diterima dari investasi, investasi sendiri ada dua jenis diantaranya investasi yang bersifat untuk jangka panjang dan investasi untuk jangka pendek.

\subsubsection{Aktiva Tetap}

Aktiva tetap ialah jenis aset yang berwujud dengan tujuan untuk memfungsikan kegiatan operasional perusahaan dan tidak dimaksudkan untuk dijual yang dibangun terlebih dahulu sebelum kegiatan operasional perusahaan yang masa manfaatnya melebihi satu tahun, aset tetap sendiri memiliki berbagai jenis seperti gedung, tanah, mesin, investasi jangka panjang atau sebagainya.

\subsubsection{Aktiva Tak Berwujud}

Aktiva tak berwujud ialah suatu jenis aktiva yang bersifat non fisik yang memberikan manfaat kepada pemiliknya baik dari hak ekonomi ataupun hak hukum atas aktiva yang dimiliki, aktiva tak berwujud jenisnya berbeda beda seperti goodwill, merk dagang, hak cipta atau juga franchise.

\subsubsection{Aktiva Lain}

Aktiva lainnya ialah aset yang bersumber selain dari aktiva tetap, aktiva tak berwujud, investasi, dan aktiva lancar seperti bangunan perusahaan yang masih dalam proses pengerjaan, piutang-piutang yang dimiliki perusahaan dan lain sebagainya.

\subsection{Return On Assets}

Return on Assets (ROA) adalah bagian dari rasio profitabilitas yang bisa memperlihatkan seberapa besar aset suatu perusahaan dapat menghasilkan pendapatan atau keuntungan bagi perusahaan apabiladibandingkan dengan seluruh aset perusahaan, sehingga rasio ini ialah salah satu rasio profitabilitas yang kerap dipakai oleh para investor dalam menilai efektivitas modal yang dimiliki perusahaan dalam menghasilkan laba dimana anajemen puncak sering menggunakan metode ini untuk menilai setiap unit bisnis perusahaan. Berdasarkan perhitungannya rasio ini biasanya dapat diketahui dengan perhitungan return on assets (ROA).

$$
\mathrm{ROA}=\frac{\text { Laba Bersih }}{\text { Total Asset }}
$$

\subsection{Return On Equity}

Return On Equity atau yang biasanya diketahui dengan nama ROE merupakan komponen rasio profitabilitas yang umumnya difungsikan untuk menilai efisiensi level atau tingkat pengembalian modal atau investasi dari laba bersih yang dihasilkan dan dapat dijadikan alat ukur abilitas perusahaan dalam mendapatkan nilai lebih dengan modal yang dimilikinya. ROE menggambarkan keahlian perusahaan kala mengelola dana ataupun modal yang dipercayakan para pemilik ekuitas pemegang saham, nilai ROE yang tinggi tentunya akan menjadi penumbuh minat investor untuk menanamkan modalnya, karena nilai ROE yang tinggi menjadi point penanda bahwa perusahaan performanya baik (Rahmadewi \& Abundanti, 2018), ROE bisa dicari dengan rumus:

$$
\mathrm{ROE}=\frac{\text { Laba Bersih }}{\text { Modal Perusahaan }} \times 100 \%
$$




\subsection{Laporan Keuangan}

Laporan Keuangan adalah rangkuman proses pencatatan transaksi-transaksi yang berhubungan dengan aktivitas keuangan yang terjadi dalam kurun waktu tahun buku yang bersangkutan (Sri Wahyuni Nur, S.E., 2020). Laporan keuangan dimaksudkan untuk memberikan informasi rinci tentang posisi keuangan perusahaan, kinerja keuangan, atau situasi arus kas, dimana informasi tersebut penting dan bermanfaat untuk proses pembuatan keputusan ekonomi yang strategis bagi pihak-pihak terkait. Laporan keuangan dibuat dimaksudkan sebagai pertanggung jawaban industri kepada pihak-pihak yang memiliki urusan dengan kinerja keungan industry yang dicapai selama periode tahun yang bersangkutan, laporan keuangan dibuat dengan prinsip-prinsip akuntansi agar tujuan dapat tercapai yakni sebagai sumber informasi atau alat bagi pemangku kepentingan internal atau eksternal untuk lebih memahami situasi keuangan perusahaan dalam rangka membuat suatu keputusan keuangan.

\section{METODE}

Dalam riset ini metode yang dipakai merupakan metode kuantitatif yakni suatu metode penelitian terstruktur dan mengkuatifikasikan data untuk dapat digeneralisasikan, dalam mengumpulkan data yang diperlukan metode yang dipakai yaitu pertama documentation method yang merupakan teknik pengumpulan informasi berupa data keuangan perusahaan yang merupakan data sekunder dimana dalam proses pengumpulan diperoleh melalui hasil penelitian observatory (pengamat) lain atau dari sumber-sumber lainnya seperti halnya BPS, mass medial, lembaga pemerintah, atau lembaga swasta dan lain sebagainya (Prof. Dr. Ir. Sugiarto, M.Sc., Ir. Hongyanto Setio, 2021), di mana sumber data diperoleh melalui serangkaian media perantara yaitu BEI yakni laporan tahunan atau annual report PT. Astra International Tbk yang bersumber dari situs resminya www.idx.co.id sebagai sumber informasi untuk bahan penelitian dan yang kedua yakni teknik kepustakaan yang dilakukan dengan cara mengumpulkan informasi mengenai topik yang sedang diteliti dari berbagai referensi baik buku-buku, jurnal penelititan terdahulu ataupun dari website-website di internet duna menambah pengetahuan dan memcahkan persoalan masalah yang sedang diteliti. Dalam melakukan penelitan guna mendapatkan hasil dari penelitian di sini peneliti menggunakan Software IBM SPSS Statistic 26.0. sebagai program atau alat yang memproses data dari sumber data yang relevan.

\subsection{Uji Variabel}

Dalam melakukan pengujian pengaruh antar variabel peneliti menggunakan software IBM SPSS Statistic 26.0 dimana dalam pengujiannya menggunakan satu variabel bebas dan menguji keterikatannya terhadap variabel terikat yang terdiri dari $Y_{1}$ dan $Y_{2}$ akan melewati beberapa tahap pengujian yang diperlukan yang akan dipaparkan di bagian metode analisi data.

\subsection{Kerangka Berpikir}

Return On Assets ataupun Return On Equity yaitu beberapa jenis dari rasio profitabilitas yang mengukur seberapa besar timbal balik atas aset-aset dan modal yang sudah di investasikan pada perusahaan yang dinilai dari penghasilan atau profit yang didapatkan perusahaan. Tinggi rendahnya Return On Asset juga Return On Equity perubahannya bisa 
serasi dengan berubahnya profit margin atau perputaran aktiva. Dengan menambahkan aktiva lancar dan atau aktiva tetap (Total Asset) sampai level tertentu diusahakan meningkatnya tambahan penjualan yang relatif besar dari tambahan Total Asset, terus membuat perputaran aktiva akan meningkat. Dengan meningkatnya perputaran aktiva berarti Return On Assets atau Return On Equity juga berkemungkinan meningkat, jadi tinggi rendahnya Total Aktiva perusahaan dapat mempengaruhi tinggi rendahnya Return On Assets ataupun Return On Equity.

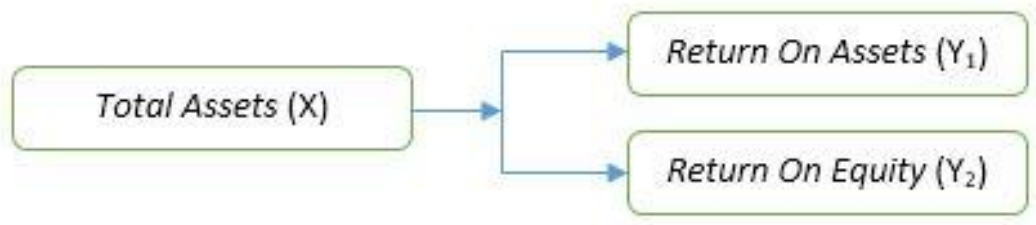

\subsection{Hipotesis}

Dari pemaparan kerangka pemikiran diatas dapat di tarik kesimpulan bahwa adanya pengaruh Total Aset pada Return On Assets dan Return On Equity pada PT. Astra International Tbk.

\subsection{Operasionalisasi Variabel}

Variabel yang dipergunakan di riset ini ialah variabel $\mathrm{X}$ (Independent) atau variabel bebas dan variabel Y (Dependent) atau variabel terikat (Muthmainnah, 2021), Variabel bebas (X), Total Asset di sini merupakan jumlah seluruh aktiva perusahaan yang dinyatakan dengan satuan rupiah yang memiliki jenis aset lancar, aset tetap dan aset lainnya, dimana data diperoleh dari annual report PT. Astra International Tbk tahun 2016-2020 yang bersumber dari www.idx.co.id.

Variabel Terikat (Y) yaitu :

a) Return On Assets ( $\left.\mathrm{Y}_{1}\right)$, dalam penelitian ini ialah perolehan tingkat pengembalian atas jumlah total aktiva yang dimiliki perusahaan pada periode akhir atau pada saat tutup buku yang diperoleh report keuangan PT. Astra International Tbk dari tahun 2016-2020 dan dinyatakan dalam persentase yang bersumber dari www.idx.co.id.

b) Retun On Equity $\left(\mathrm{Y}_{2}\right)$, ialah tingkat perolehan atas hasil ekuitas para pemilik modal perusahaan pada saat tutup buku atau periode akhir yang diperoleh dari data keuangan PT. Astra International Tbk tahun 2016-2020 dinyatakan dalam persentase yang bersumber dari www.idx.co.id.

\subsection{Metode Analisis Data}

1. Uji Statistik Deskriptif, yakni suatu metode dalam ilmu statistik yang dapat memberikan gambaran secara umum yang dilihat dari output variabel bebas (independent) juga variabel terikat (dependent), dimana analisis ini merupakan pendekatan deskriptif yang memberikan informasi atau gambaran tentang fakta-fakta yang dimiliki dan tidak

2. bertujuan menguji hipotesis. 
3. Uji Asumsi Klasik, yakni suatu analisis yang dilakukan dalam menilai suatu model regresi linear mempunyai permasalahan asumsi klasik, dimana uji ini juga merupakan syarat yang harus dipenuhi pada suatu model regresi linear agar model tersebut valid dan dapat digunakan sebagai suatu penaksir, dalam uji asumsi klasik ini ada beberapa jenis uji yang paling umum dipakai ialah uji normalitas.

4. Analisis Regresi Linier Sederhana, yakni bagian dari metode regresi yang digunakan sebagai suatu alat inferensi statistik untuk menentukan pengaruh dari variabel bebas (X) terhadap variabel terikat (Y), yang dapat dirumuskan seperti berikut.

$$
\begin{aligned}
& Y_{1}=a+b X+e \\
& Y_{2}=a+b X+e
\end{aligned}
$$

Deskripsi :

$$
\begin{array}{ll}
\mathrm{Y}_{1} & =\text { Return On Assets } \\
\mathrm{Y}_{2} & =\text { Return On Equity } \\
\mathrm{X} & =\text { Total Assets } \\
\mathrm{a} & =\text { Konstanta } \\
\mathrm{b} & =\text { Koefisen Variabel X }
\end{array}
$$

Uji Hipotesis dikerjakan dengan uji variabel sebagai berikut :

a) Uji Simultan (Uji F), Adalah untuk mengamati bagaimana seluruh faktor independent berinteraksi untuk menginterfensi variabel dependent atau untuk melihat apakah model regresi yang dibuat baik (signifikan) atau tidak (tidak signifikan). Uji statistik F pada dasarnya memperlihatkan apakah keseluruhan variabel bebas yang di input dalam model mempunyai pengaruh secara bersamasama terhadap variabel terikat (Wicaksono, 2020).

b) Uji Parsial (Uji t), Merupakan pengujian yang digunakan untuk menilai setiap variabel bebas mempengaruhi variabel terikat, yang umumnya menggunakan uji tstatistic atau uji Z-statistik, Uji statistik t pada intinya memperlihatkan seberapa berpengaruhnya satu variabel independent secara individual dalam menjabarkan variasi variabel dependeni (Martinus \& Budiyanto, 2016).

5. Uji Koefisien Determinasi, yaitu untuk mencari hasil output koefisien determinasi parsial per-sub variabel independent (r2) dan besaran total koefisien determinasi (R2), uji ini bermaksud mencari tahu sebarapa jauh model regresi dapat menerangkan variabel dependent penelitian (Winanti et al., 2017).

\section{HASIL DAN PEMBAHASAN}

\subsection{Uji Statistik Deskriptif}

Tabel 1. Hasil Uji Statistik Deskriptif

Descriptive Statistics

\begin{tabular}{lrr|r|r|r} 
& $N$ & Minimum & Maximum & \multicolumn{1}{c}{ Mean } & \multicolumn{1}{c}{ Std. Deviation } \\
\hline X_Total_Assets & 5 & 261855 & 351958 & 318511.40 & 38461.821 \\
\hline Y1_ROA & 5 & $5.00 \%$ & $8.00 \%$ & $7.2000 \%$ & $1.30384 \%$ \\
\hline Y2_ROE & 5 & $10.00 \%$ & $16.00 \%$ & $13.6000 \%$ & $2.30217 \%$ \\
\hline Valid N (listwise) & 5 & & & & \\
\hline
\end{tabular}


Dari tabel statistic deskriptif diatas dengan jumlah data (N) sebanyak 5 sampel, didapatkan hasil nilai Minimum untuk variabel independent X atau Total Assets yaitu 261855, nilai tertinggi 351958, nilai rata-rata (Mean) 318511.40 dan standart Deviasi 38461.821 sementara untuk variabel dependent Y1 atau ROA nilai Minimum sebesar 5\% dan Y2 atau ROE 10\%, untuk nilai Maximum Y1 di angka 8\% dan Y2 di angka 16\%, kemudian nilai ratarata (Mean) Y1 berada di $7.2 \%$ dan Y2 $13.6 \%$ sementara untuk nilai Standart Deviasi Y1 sebesar $1.30384 \%$ dan Y2 $2.30217 \%$.

\subsection{Uji Asumsi Klasik Uji Normalitas}

\section{One-Sample Kolmogorov-Smirnov Test}

\begin{tabular}{|c|c|c|c|c|}
\hline & & X_Total_Assets & Y1_ROA & Y2_ROE \\
\hline $\mathrm{N}$ & & 5 & 5 & 5 \\
\hline \multirow[t]{2}{*}{ Normal Parameters ${ }^{a, b}$} & Mean & 318511.40 & $7.2000 \%$ & $13.6000 \%$ \\
\hline & Std. Deviation & 38461.821 & $1.30384 \%$ & $2.30217 \%$ \\
\hline \multirow[t]{3}{*}{ Most Extreme Differences } & Absolute & .296 & .330 & .197 \\
\hline & Positive & .192 & .270 & .149 \\
\hline & Negative & -.296 & -.330 & -.197 \\
\hline Test Statistic & & .296 & .330 & .197 \\
\hline Asymp. Sig. (2-tailed) & & $.176^{\mathrm{c}}$ & $.079^{\mathrm{c}}$ & $.200^{c, d}$ \\
\hline \multicolumn{5}{|c|}{$\begin{array}{l}\text { a. Test distribution is Normal. } \\
\text { b. Calculated from data. } \\
\text { c. Lilliefors Significance Correction. } \\
\text { d. This is a lower bound of the true significance. }\end{array}$} \\
\hline
\end{tabular}

Sumber : Hasil olah data IBM SPSS Statistic 26.0

Uji tersebut diatas memeperlihatkan untuk angka Asymp. Sig. (2-tailed) untuk Total

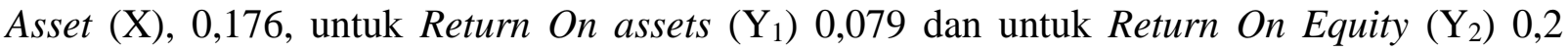
dimana pengambilan keputusan didasarkan apabila angka Asymp. Sig. (2-tailed) diatas 0,05 maka output hasil uji menyatakan mempunyai distribusi data normal, dan variabel sudah layak di uji maka dari uji One-Sample Kolmogorov-Smirnov Test, menunjukan variabel berdistribusi normal dan sudah layak untuk di uji.

\section{Uji Autokorelasi}

Dalam uji autokorelasi pada kasus penelitian pengaruh Total Asset terhadap Return On Assets dan Return On Equity menggunakan uji run test pada program SPSS, dalam uji run test ini terdapat dua pengujian yaitu Total Asset (X) pada Return On Assets ( $\left.\mathrm{Y}_{1}\right)$ dan Total Asset (X) pada Return On Equity $\left(\mathrm{Y}_{2}\right)$.

Tabel 2. Uji Autokorelasi X terhadap $\mathrm{Y}_{1}$

\section{Runs Test}

Unstandardized Residual 
CIbnu Sabil Al ansori ${ }^{*}$, Ratnoto ${ }^{2}$, Mutmainnah $^{3}$

\begin{tabular}{lr}
\hline Test Value $^{\mathrm{a}}$ & .79073 \\
\hline Cases $<$ Test Value & 2 \\
\hline Cases $>=$ Test Value & 3 \\
\hline Total Cases & 5 \\
\hline Number of Runs & 3 \\
\hline$Z$ & .000 \\
\hline Asymp. Sig. (2-tailed) & 1.000 \\
\hline a. Median
\end{tabular}

Tabel 3. Uji Autokorelasi $\mathrm{X}$ terhadap $\mathrm{Y}_{2}$

\section{Runs Test}

\begin{tabular}{lr} 
& $\begin{array}{c}\text { Unstandardized } \\
\text { Residual }\end{array}$ \\
\hline Test Value & .35700 \\
\hline Cases $<$ Test Value & 2 \\
\hline Cases $>=$ Test Value & 3 \\
\hline Total Cases & 5 \\
\hline Number of Runs & 3 \\
\hline$Z$ & .000 \\
\hline Asymp. Sig. (2-tailed) & 1.000 \\
\hline a. Median
\end{tabular}

Sumber : Hasil olah data IBM SPSS Statistic 26.0

Berdasarkan Uji analisis run test dasar pengambilan keputusan hasil uji output nya ialah apabila angka Asymp. Sig. (2-tailed) kurang dari 0,05 maka menunjukan adanya tandatanda autokorelasi tetapi apabila nilai Asymp. Sig. (2-tailed) melebihi dari 0,05 kemudian dapat disimpulkan tidak adanya gejala autokorelasi.

Dari hasil uji SPSS diatas dapat dilihat bahwa nilai Asymp. Sig. (2-tailed) untuk uji X dan Y1 ialah 1,000 itu itu artinya tidak punya gejala atau masalah autokorelasi begitu pula dengan hasil uji $\mathrm{X}$ dan $\mathrm{Y}_{2}$ angka Asymp. Sig. (2-tailed) di angka 1,000 menunjukan output hasil uji $\mathrm{X}$ dan $\mathrm{Y}_{1}$ maupun $\mathrm{X}$ dan $\mathrm{Y}_{2}$ tak bermasalah atau tidak didapatkan autokorelasi dalam uji run test dan kemudian analisis regresi linear bisa diteruskan.

\subsection{Uji Regresi Sederhana}

Dalam uji regresi terdapat dua uji yakni uji $\mathrm{F}$ dan uji t yang dimaksud untuk mengetest hipotesis pengaruh antar variabel independent dan variabel dependent.

a) Uji F

Tabel 3. Uji F untuk $Y_{1}$

\section{ANOVA $^{a}$}

\begin{tabular}{ll|r|r|r|r|r} 
Model & Sum of Squares & df & Mean Square & F & Sig. \\
\hline 1 & Regression & .001 & 1 & .001 & .000 & $.985^{\mathrm{b}}$ \\
\cline { 2 - 8 } & Residual & 6.799 & 3 & 2.266 & & \\
\cline { 2 - 8 } & Total & 6.800 & 4 & & & \\
\hline
\end{tabular}

a. Dependent Variable: Y1_ROA

b. Predictors: (Constant), X_Total_Assets 
Tabel 4. Uji F untuk $\mathrm{Y}_{2}$

ANOVA $^{a}$

\begin{tabular}{ll|r|r|r|r|r} 
Model & Sum of Squares & df & Mean Square & F & Sig. \\
\hline 1 & Regression & .010 & 1 & .010 & .001 & $.973^{\mathrm{b}}$ \\
\cline { 2 - 8 } & Residual & 21.190 & 3 & 7.063 & & \\
\cline { 2 - 8 } & Total & 21.200 & 4 & & & \\
\hline
\end{tabular}

a. Dependent Variable: Y2_ROE

b. Predictors: (Constant), $\mathbf{X}$ _Total_Assets

Sumber : Hasil olah data IBM SPSS Statistic 26.0

Dari hasil uji tabel anova ${ }^{a}$ diperoleh nilai $F$ hitung untuk $X$ dan $\mathrm{Y}_{1}$ sebesar 0,000 dan tingkat signifikansi 0,985 dimana kemudian untuk nilai $\mathrm{F}$ hitung antar $\mathrm{X}$ dan $\mathrm{Y}_{2}$ didaptkan nilai 0,001 dan signifikansi 0,973 dimana apabiladiambil dari dasar keputusan yang diambil apabila angka signifikansi diatas 0,05 maka berarti hasil penelitian menunjukan tidak adanya saling ketergantungan variabel independent dan variabel dependent berbeda apabilaangka signifikansi kurang dari 0,05, hal ini menunjukkan bahwa variabel bebas berpengaruh terhadap variabel terikat, kemudian dasar pengambilan keputusan yang lain ialah apabilaF hitung bernilai lebih besar dari $\mathrm{F}$ tabel maka menunjukan adanya pengaruh antara variabel indendent terhadap variabel dependent dan sebaliknya apabilanilai $\mathrm{F}$ hitung tidak lebih dari $\mathrm{F}$ tabel maka hasil uji terindikasi tidak terjadi pengaruh antara variabel independent terhadap variabel dependent, diketahui bahwa nilai $F$ tabel untuk data $X$ dan $Y_{1}$ maupun $X$ dan $Y_{2}$ ialah 7,71 itu artinya angka $\mathrm{F}$ tabel lebih dari angka $\mathrm{F}$ hitung maka dapat disimpulkan hasil uji $\mathrm{F}$ antar variabel independent $\mathrm{X}$ dan $\mathrm{Y}_{1}$ maupun $\mathrm{X}$ dan $\mathrm{Y}_{2}$ tidak memberikan pernyataan atau hasil adanya keterkaitan antar variabel uji.

b) Uji t

Tabel 5. Uji t untuk $Y_{1}$ Coefficients $^{a}$

\begin{tabular}{|c|c|c|c|c|c|c|}
\hline \multirow[b]{2}{*}{ Model } & & \multicolumn{2}{|c|}{ Unstandardized Coefficients } & \multirow{2}{*}{$\begin{array}{c}\text { Standardized } \\
\text { Coefficients } \\
\text { Beta }\end{array}$} & \multirow[b]{2}{*}{$\mathrm{t}$} & \multirow[b]{2}{*}{ Sig. } \\
\hline & & $\mathrm{B}$ & Std. Error & & & \\
\hline 1 & (Constant) & 7.330 & 6.270 & & 1.169 & .327 \\
\hline & X_Total_Assets & $-4.087 \mathrm{E}-7$ & .000 & -.012 & -.021 & .985 \\
\hline
\end{tabular}

a. Dependent Variable: Y1_ROA

Tabel 6. Uji t untuk $\mathrm{Y}_{2}$

Coefficients $^{\mathrm{a}}$

\begin{tabular}{|c|c|c|c|c|c|c|}
\hline \multirow{2}{*}{\multicolumn{2}{|c|}{ Model }} & \multicolumn{2}{|c|}{ Unstandardized Coefficients } & \multirow{2}{*}{$\begin{array}{c}\text { Standardized } \\
\text { Coefficients } \\
\text { Beta }\end{array}$} & \multirow[b]{2}{*}{$\mathrm{t}$} & \multirow[b]{2}{*}{ Sig. } \\
\hline & & B & Std. Error & & & \\
\hline \multirow[t]{2}{*}{1} & (Constant) & 13.190 & 11.069 & & 1.192 & .319 \\
\hline & X_Total_Assets & $1.286 \mathrm{E}-6$ & .000 & .021 & .037 & .973 \\
\hline
\end{tabular}

a. Dependent Variable: Y2_ROE

Sumber : Hasil olah data IBM SPSS Statistic 26.0

Yang terlihat hasil uji t untuk uji pengaruh $\mathrm{X}$ terhadap $\mathrm{Y}_{1}$ didapat hasil $\mathrm{T}$ hitung dengan nilai 1,169 dan signifakansi 0,372 sementara untuk uji pengaruh $\mathrm{X}$ terhadap $\mathrm{Y}_{2}$ didapat output $\mathrm{t}$ 
hitung di angka 1,192 dan signifikansi 0,319 sementara untuk nilai t tabel baik untuk $\mathrm{X}$ terhadap $\mathrm{Y}_{1}$ dan $\mathrm{X}$ terhadap $\mathrm{Y}_{2}$ mempunyai nilai yang sama yakni 2,35336 dengan dasar standart signifikansi 0,05 , maka diketahuilah bahwa nilai t hitung untuk kedua uji t diatas dibawah t tabel yakni 2,35336 begitu pun untuk angka signifikansi dari kedu uji diatas yakni lebih besar > dari 0,05 berdasarkan dasar pengambilan keputusan bahwa kalau angka t hitung melebihi angka dari t tabel dan angka signifikansi dibawah angka 0,05 maka terdapat pengaruh antara variabel independent dan variabel dependent dan sebaliknya kalau angka t hitung tidak lebih dari t tabel dan nilai signifkansi diatas 0,05 maka menandakan tidak ada kaitan antara $\mathrm{X}$ atas Y.

\subsection{Uji Koefisien Determinasi}

Tabel 7 . Uji Koefisien Determinasi $Y_{1}$

\begin{tabular}{|c|c|c|c|c|}
\hline \multicolumn{5}{|c|}{ Model Summary } \\
\hline Model & $\mathrm{R}$ & R Square & $\begin{array}{l}\text { Adjusted R } \\
\text { Square }\end{array}$ & $\begin{array}{l}\text { Std. Error of the } \\
\text { Estimate }\end{array}$ \\
\hline 1 & $.012^{\mathrm{a}}$ & .000 & -.333 & $1.50544 \%$ \\
\hline
\end{tabular}

Tabel 8 . Uji Koefisien Determinasi $\mathrm{Y}_{2}$

\section{Model Summary}

\begin{tabular}{lr|r|r|r} 
Model & $\mathrm{R}$ & R Square & \multicolumn{1}{c|}{$\begin{array}{c}\text { Adjusted R } \\
\text { Square }\end{array}$} & $\begin{array}{l}\text { Std. Error of the } \\
\text { Estimate }\end{array}$ \\
\hline 1 & $.021^{\mathrm{a}}$ & .000 & -.333 & $2.65771 \%$ \\
\hline
\end{tabular}

a. Predictors: (Constant), X_Total_Assets

Sumber : Hasil olah data IBM SPSS Statistic 26.0

Data diatas memperlihatkan nilai untuk $\mathrm{X}$ terhadap $\mathrm{Y}_{1}$ dan $\mathrm{X}$ terhadap $\mathrm{Y}_{2}$ didapatkan nilai $\mathrm{R}$ Square 0,000 dan adjusted $\mathrm{R}$ Square $-0,333$ berhubung dalam penelitian ini hanya terdapat satu variabel $\mathrm{X}$ maka digunakan nilai $\mathrm{R}$ Square yakni sebesar 0,000 dimana berdasarkan teknik pengambilan keputusan apabila nilai R Square kurang dari $<0,05$ maka uji yang dilakukan membuktikan bahwa antara variabel $\mathrm{X}$ dan $\mathrm{Y}$ tidak berkaitan, jadi bisa ditarik hasil bahwa Total Asset bukan faktor yang berpengaruh untuk Return On Assets dan Return On Equity dan berarti ada faktor external diluar pembahasan ini yang mempengaruhi nilai $\mathrm{Y}_{1}$ dan $\mathrm{Y}_{2}$ dan dalam penelitian ini variabel $\mathrm{X}$ sebagai Total Asset tidak terlibat terhadap perubahan nilai Return On Assets juga Return On Equity.

\section{KESIMPULAN}

Dari pembahasan diatas kesimpulan yang dapat ditarik bahwa nilai Total Asset perusahaan tidak secara signifikan mempengaruhi Return On Assets ataupun Return On Equity, pernyataan tersebut diperoleh dari hasil uji regresi dari pemaparan di pembahasan, baik dari uji F maupun uji t menghasilkan kesimpulan atau hasil yang memberikan bantahan terhadap hipotesis tentang adanya pengaruh Total Asset pada Return On Assets dan Return On Equity begitu pula dari uji koefisien determinasi $\left(\mathrm{R}^{2}\right)$ yang menunjukan bahwa nilai pengaruh variabel 
$\mathrm{X}$ terhadap $\mathrm{Y}_{1}$ dan $\mathrm{Y}_{2}$ adalah 0,000 yang berarti nilai pengaruhnya ialah $0 \%$, dan dalam hasil penelitian ini total aset bukan merupakan faktor yang mempengaruhi perubahan nilai ROA ataupun ROE selama periode tahun 2016-2020 di PT. Astra International Tbkmelainkan ada faktor lain yang mempengaruhinya, dan berarti jumlah modal atau aset perusahaan bukan penentu sebuah perusahaan dapat menghasilkan Return yang tinggi namun, pertimbangan yang paling penting adalah bagaimana organisasi dapat meningkatkan kinerja perusahaannya secara keseluruhan., perusahaan yang berkinerja baik setidaknya dapat menstabilkan hasil Return dari aset ataupun modal yang dimilikinya dalam kurun waktu tertentu sebanding dengan aset dan modal yang dimilikinya.

\section{Saran}

Dari penelitian ini peneliti ingin menambahkan beberapa saran diantaranya :

1. Bagi perusahaan, peneliti berharap supaya perusahaan bisa meningkatkan kualitas kinerja keuangannya, sehingga dapat memaksimalkan penggunaan aset-aset perusahaan agar dapat meningkatkan nilai rasio Return On Assets maupun Return On Equity, karena kedua rasio tersebut seringkali dijadikan bahan pertimbangan para calon investor untuk berinvestasi, sehingga diharapkan dapat meningkatkan jumlah modal perusahaan dan dapat mengembangkan perusahaan di berbagai sektor yang dijalankan dalam rangka meningkatkan penguasaan pasar dan kuantitas penjualan.

2. Riset ini dimaksudkan agar dapat bermanfaat bagi masyarakat umum atau investor masa depan bagaimana menentukan perusahaan yang layak dijadikan acuan untuk berinvestasi, dan para investor perlu memperhatikan faktor-faktor lain yang lebih realistis sebagai pertimbangan dalam memutuskan untuk berinvestasi.

3. Bagi peneliti sendiri berharap dari penelitian ini, agar bisa menjadi wawasan yang bermanfaat untuk menambah ilmu pengetahuan dan semoga peneliti dapat menguji variabel atau faktor lain yang dapat menginterfensi Return On Assets dan Return On Equity, ataupun peneliti dapat menambah periode penelitian atau mencoba menguji variabel terhadap perusahaan lain dengan jenis industri yang berbeda sebagai perbandingan.

\section{REFERENSI}

Andini, R., \& Kharisma, F. (2021). Pengaruh Jumlah Aset dan Laba Terhadap Utang di Perusahaan Indeks LQ 45 Pada Tahun 2018-2019. Borneo Student Research (BSR), 2(2), 1355-1362.

Martinus, E., \& Budiyanto, B. (2016). Pengaruh Kompensasi Dan Motivasi Kerja Terhadap Kinerja Karyawan Pada PT. Devina Surabaya. Jurnal Ilmu Dan Riset Manajemen (JIRM), $5(1)$.

Muthmainnah. (2021). Pengaruh Inflasi Terhadap Penjualan Sepeda Motor Di Indonesia. E-Bis (Ekonomi-Bisnis), 5 No.1, 218-227. https://doi.org/https://doi.org/10.37339/jurnal ebis.v5i1.429 
Prof. Dr. Ir. Sugiarto, M.Sc., Ir. Hongyanto Setio, M. (2021). STATISTIKA TERAPAN UNTUK BISNIS DAN EKONOMI. Penerbit Andi.

Rahmadewi, P. W., \& Abundanti, N. (2018). Pengaruh EPS, PER, CR dan ROE terhadap harga saham di Bursa Efek Indonesia. Udayana University.

Siska Devi Ratna Sari S.Kom.I., M. S. (2020). Fungsi Aset Komunitas Dalam Pemberdayaan Masyarakat Muslim. Profitebel.

Sofwan, S. V., \& Sulastri, T. (2019). PERAN PUSAT PEMULIHAN ASET DI KEJAKSAAN NEGERI BANDUNG. AKURAT| Jurnal Ilmiah Akuntansi FE UNIBBA, 10(3), 151-165.

Sri Wahyuni Nur, S.E., M. A. (2020). Akuntansi Dasar: Teori dan Teknik Penyusunan Laporan Keuangan. Cendekia Publisher.

Wicaksono, D. (2020). ANALISIS PENGARUH UKURAN PERUSAHAAN DAN KOMISARIS INDEPENDEN TERHADAP PENGUNGKAPAN INTELLECTUAL CAPITAL DENGAN PROFITABILITAS SEBAGAI VARIABEL MODERASI. Kinerja, $3(1), 123-138$.

Winanti, E., Nurlaela, S., \& Titisari, K. H. (2017). Pengaruh Rasiolikuiditas, Rasio Produktivitas, Rasio Profitabilitas, Dan Rasio Solvabilitas Terhadap Peringkat Sukuk. Jurnal Akuntansi Dan Pajak, 18(01). 